\title{
LIBERTY

\section{The Efficacy of a Manualized Group Treatment Protocol for Changing God Image, Attachment to God, Religious Coping, and Love of God, Others, and Self}

\author{
Jacqueline D. Rasar \\ Liberty University, jdrasar@liberty.edu \\ Fernando L. Garzon \\ Liberty University, fgarzon@liberty.edu \\ Frederick Volk \\ Liberty University, fvolk@liberty.edu \\ Carmella A. O'Hare \\ Liberty University \\ Glendon L. Moriarty \\ Regent University
}

Follow this and additional works at: https://digitalcommons.liberty.edu/ccfs_fac_pubs

Part of the Christianity Commons, and the Counseling Commons

\section{Recommended Citation}

Rasar, J., Garzon, F., Moriarty, G., Volk, F., \& O'Hare, C. (2013). The Efficacy of a manualized group treatment protocol for changing God image, attachment to God, religious coping, and love of God, others, and self. Journal of Psychology and Theology, 41, 267-280.

This Article is brought to you for free and open access by the Department for Counselor Education and Family Studies at Scholars Crossing. It has been accepted for inclusion in Faculty Publications and Presentations by an authorized administrator of Scholars Crossing. For more information, please contact scholarlycommunications@liberty.edu. 


\section{The Efficacy of a Manualized Group Treatment Protocol for Changing God Image, Attachment to God, Religious Coping, and Love of God, Others, and Self}

Jacqueline D. Rasar, Fernando L. Garzon, Frederick Volk, and Carmella A. O'Hare

Liberty University

Glendon L. Moriarty

Regent University

This study compared the efficacy of a manualized group treatment protocol on God image and attachment to God to a manualized Christian Bible study and a waiting list control group in a sample of undergraduate college students attending a Christian college. Thirty students were randomly assigned to one of the treatment conditions and assessed with measures of God attachment, God image, religious coping, and general spiritual outcomes. It was hypothesized that significant God image and attachment change would occur among the God image treatment group participants only. In addition, it was hypothesized that significant religious coping and spiritual outcome change would occur within both groups compared to the waiting list control group. The results supported significant spiritual outcome changes in both groups but no significant God image/attachment change or religious coping change. Feedback from group participants informed how manualized God image/attachment protocols may be modified in future research to improve outcomes for young college-age Christian participants.

For many years, God image development has been a topic in the psychology of religion literature (Rizzuto,
1974; Rizzuto, 1979; McDargh, 1986; Hall, 2004; Peloso, 2008). God attachment has also become a major area of exploration (Birky \& Ball, 1988; Kirkpatrick \& Shaver, 1992; Kirkpatrick, 1992; Kirkpatrick, 1999; Granqvist \& Hagekull, 1999; McDonald, Beck, Allison, \& Norsworthy, 2005; Beck, 2006; Hall, Fujikawa, Halcrow, Hill, \& Delaney, 2009). While much theoretical development has occurred in understanding these constructs, true experimental studies examining how individual or group therapy can impact these constructs are limited.

The purpose of this study was to assess the effects of a manualized group treatment protocol on God image and attachment to God in a sample of undergraduate college students attending a conservative Christian college. The treatment group manual (entitled "Discovering God") was designed to help individuals within the Christian tradition to experience God in a manner more congruent with their cognitive understanding and included psychoeducational, dynamicinterpersonal, cognitive interventions, bibliotherapy, and art/music interventions (also used in a pilot study by Thomas et al., 2011). The Bible Study group manual (entitled "Spiritual Life Group") was designed as a spiritual formation-focused Bible study and included 
psychoeducational, dynamic-interpersonal, cognitive interventions, bibliotherapy, and art/music interventions (Rasar, 2010).

\section{Definitions and Development}

\section{Definitions}

As a psychological construct, God images are persons' affect-laden mental representations that underlie their embodied, emotional experiences in relationship with God (Davis, 2010). They involve implicit relational knowledge that guides how people experience God at a largely nonverbal, emotional, physiological, and frequently implicit level (Moriarty \& Davis, in press; cf. Hall, 2004). God images thus may be conceptualized as attachment filters that mediate people's emotional experience with God (Hall, 2007). The God image is a psychological construct concerned with how an individual feels toward God and one's impression of how God feels about him or her (Grimes, 2007). People vary greatly in their God images. For example, some may experience God as loving and kind while others inwardly experience Him as harsh, judgmental, or distant.

God image stands in contrast to God concept, which is best defined as a person's belief-laden, intellectual, understanding of God. It includes the personality traits and qualities that an individual cognitively ascribes to God which mediate one's theological ideas and abstract thoughts about God (Thomas et al., 2011; cf. Davis, 2010). God concepts mainly derive from formal and informal learning (Hoffman, 2005). For example, people from the Christian tradition generally are taught and believe that God is creator, omnipresent, omnipotent, and omniscient. God attachment as a construct draws from Bowlby's $(1969,1982)$ work. Kirkpatrick (1999) asserts that foundational concepts of the attachment theory-the presence of an available and responsive attachment figure, who serves as a secure base, and separation from whom results in distress-are fundamental dynamics of Christianity; therefore, a relationship with God can be explained as an attachment bond. Consistent with Bowlby's ideas, which have been expanded by Ainsworth (1985), God may serve positively as a secure base in which $\mathrm{He}$ is a safe haven in times of distress and a solid inner foundation to explore one's environment. Conversely, insecure attachment to God can create spiritual and emotional distress (Kirkpatrick, 1999). Some research has correlated both secure attachment to a primary caregiver with a secure attachment to God (Birky \& Ball, 1988), and insecure attachment to a primary caregiver with an insecure attachment to God (McDonald, Beck, Allison, \& Norsworthy, 2005). Nevertheless, those with an anxious, avoidant, or ambivalent type of insecure attachment to parents may at times still develop a secure attachment with God in which God compensates for the lack of secure parental attachment (Kirkpatrick \& Shaver, 1990).

\section{God Image and God Attachment Development}

For a comprehensive review of God image development, see Moriarty and Davis (in press). Object relations theory (e.g., Klein, 1930/1964) and attachment theory (e.g., Bowlby, 1969) provide the theoretical underpinnings for God image and God attachment. Both of these theories have a solid research foundation in general. In particular, God image development (Rizzuto, 1979; Hall, 2004) and God attachment development (Kirkpatrick, 1992) begins in childhood and persists throughout the lifespan; yet, God image and God attachment change are theoretically possible through treatment (Rizzuto, 1974; Jacques, 1998; Fosshage, 2003; Garzon, 2007; Sperry, 2005; Schore, 2002).

Hall's (2004) implicit relational knowledge correspondence hypothesis conceptualizes God image development and is based on five central organizing principles, including (a) people are motivated by and develop in emotionally significant relationships, (b) emotional information processing provides the framework for shaping patterns in relationships with God, self, and others, (c) implicit relational representations are encoded in the mind and serve as the implicit relational knowledge of how significant relationships work, (d) early relationships with caregivers shape appraisal and meaning of subsequent relationships, and (e) these implicit relational representations form the foundation of one's knowledge of self and are processed automatically (pp. 68-74). Further research by Hall and his colleagues (Hall, Halcrow, Hill, \& Delaney, 2005) suggests implicit relational knowledge informs and corresponds with one's implicit religious or spiritual functioning, which is the emotional relationship with God. People have both implicit religious/spiritual functioning and explicit religious/spiritual functioning (i.e religious/spiritual behaviors), but implicit relational knowledge is not reflected in the latter (Hall et al., 2005).

Many theoretical articles have postulated the potential effects of individual psychotherapy on God images (Jacques, 1998; Fosshage, 2003; Garzon, 2007; Sperry, 2005; Schore, 2002); however, actual empirical studies are few. Two models relating to God as an attachment figure are the correspondence model and the compen- 
satory model (Hall, 2007). The correspondence model suggests that attachment patterns among people are reflected in attachment patterns to God. The compensatory model states that God functions as a substitute attachment figure for those with an insecure attachment pattern. Beck and MacDonald (2004) have attempted to tie the two competing theories together in a more cohesive fashion, suggesting they are both valid, but each becomes more prominent under certain circumstances. Due to inconsistent research findings on these models, the implicit relational knowledge correspondence hypothesis (Hall et al., 2005) has provided some additional clarity for both God image and God attachment development.

\section{God Image and God Attachment Treatment and Change}

Experimental studies examining how individual or group therapy can impact these constructs are limited and preliminary. Key (1995) explored the impact of inpatient psychiatric treatment on self-esteem, object relations maturity and God image, followed by outpatient therapy in a sample of 30 adult individuals. Improved self esteem, object relations maturity, and God image were maintained at a 12-month follow-up. Tisdale et al. (1997) used a religiously-adapted object relations therapy aimed at improving self-esteem and God image in 99 inpatient participants. Results indicated improved self-esteem. Cheston, Piedmont, Eanes, and Lavin (2003) investigated the change in images of God in 30 individuals in the treatment group engaged in outpatient individual therapy that was not explicitly religious or spiritual. Compared to a waiting list control group $(n=68)$, the treatment group reported a decrease in psychological symptoms and an increase in positive experiences of God. This study suggests God image change may be indirectly impacted by psychotherapy.

Empirical studies have supported group therapy as efficacious for a variety of presenting problems (McDermut, Miller, \& Brown, 2001; Gorey, Richter, \& Snider, 2001; Barlow, Burlingame, \& Fuhriman, 2000). Group therapy specifically aimed at improving God images has shown promising preliminary results (O'Hare, 2003; Thomas et al., 2011). O'Hare's (2003) pilot study on six individuals indicated that group work may improve the God image.

Thomas et al. (2011) tested the effect of a manualized group treatment protocol on God image. Results supported significant increases in the emotional experience of God as intimate, accepting, and supportive. Also, significant decreases in experiencing God as dis- tant, harsh, and disapproving were noted. The participants also reported a significantly more secure and less avoidant and less anxious attachment to God. There was a lack of a control group and a mixed nature of participant treatment (ten participants were engaged in individual therapy for at least a portion of the study) with presenting problems including depression, anxiety, and bi-polar disorder.

Thomas et al. (2011) confirmed the potential group work has for improving the God image; however, no study in the God attachment literature (individual or group therapy-focused) utilized random assignment, a comparable group, and a control group. Accordingly, the current study begins to address this gap in the literature. Applying the same manualized protocol as was used in the Thomas et al. (2011) study, we sought to assess the effects of a manualized group treatment protocol. We compared the treatment group to a manualized Bible study control group and a wait-list control group on God image and attachment to God in a sample of undergraduate college students attending a conservative Christian college. We hypothesized that the Thomas et al. (2011) group protocol would demonstrate improved God image and attachment compared to the manualized Bible study and wait-list control groups. We also hypothesized that both the group treatment and the Bible study would reflect improved religious coping and improved general spiritual outcomes compared to the wait-list control group.

\section{Method}

\section{Participants}

After Institutional Review Board (IRB) approval, participants were solicited from a Baptist-affiliated college student community. The inclusion criteria were as follows: (a) participants must be between the ages of 18 and 29; (b) enrolled as an undergraduate college student at the college; (c) not currently a Spiritual Life Leader (a campus leadership role which includes facilitating prayer groups with peers); and (d) self-reported to be within the Christian tradition. Exclusion criteria included: (a) presence of significant psychological distress or pathology; this information came from the Client Demographic Form and the screening interview; and (b) limited capacity for insight that is needed for this type of treatment. The screening interview assisted in making this determination.

Of the 96 students who completed the study materials, 36 were identified as eligible participants and volunteered for the study. Thirty participants completed the nine-week study. The dropout rate overall for this 
study was $16.6 \%$. Attrition resulted from general life issues that arose in the life of some participants resulting in a decision to not complete the study.

The participants had a mean age of 20 years and a mean education level of college sophomore. Twelve participants were male and 18 were female. Ninetyseven percent of the participants were single. Eightyseven percent of the participants had an annual income ranging from $\$ 0$ to $\$ 10,000$. Ninety-three percent of the participants were White/Caucasian.

\section{Design and Procedure}

A randomized control group pretest-posttest design was used in this study. The study was promoted through chapel services, campus wide e-mails, and personal communication with students who met the inclusion criteria. It was presented to the student population as an optional group process designed to help people compare and contrast their emotional and theological ideas of God.

The student body was given the opportunity to take the Attachment to God Inventory (AGI; Beck \& McDonald, 2004) at the conclusion of a weekly chapel service $(n=96)$. They could also opt out. It was emphasized that there were no "correct" answers to the survey questions; rather, the project was to get a sense of their genuine experience. Students who revealed problems related to their emotional experience of God on the AGI were specifically targeted as porential participants $(n=40)$ and were given a screening interview if they endorsed interest on the survey. This interview consisted of an informed consent procedure and an inclusion criteria interview to determine whether he or she was appropriate for group therapy aimed at improving God image and attachment to God. Thirty-six were deemed eligible.

The consenting participants $(N=30)$ were randomly assigned to one of three groups-the treatment group $(n=11)$, the Bible study group $(n=10)$, and the wait-list control group $(n=9)$-by a randomized block design procedure to ensure that each group had an approximately equal pre-test mean.

The treatment group and Bible study group met for nine 55-minute sessions. Absences from the group were strongly discouraged, but in the case of an absence, the group member met individually with one of the group leaders for an individual session that covered the content of the missed session. The wait list control group met twice, primarily for assessment purposes. The first meeting was during week one of the other two groups. The second meeting was during week nine of the other two groups. The members of the Bible study group and wait list control group were given the option of participating in the treatment group protocol following the conclusion of this study. Group members were given a debriefing form at the conclusion of the group process. The same instruments were administered to the participants following the last group session, excluding the Indiscriminate Proreligiousness Scales Personal Form (IPS).

\section{Setting}

This study was conducted at a Baptist-affiliated college in the South. At the present time, students pursue undergraduate degrees in ministry (pastoral training, youth ministry, Christian education, and missions) and non-ministry programs (teacher education, psychology, business, pre-nursing, history, music, and English). Every student, regardless of degree program, is required to give personal testimony and accompanying references attesting to personal Christian faith and pursues a Bible major. The 2010-2011 student body was comprised of 280 students from fourteen states and five foreign countries. The school presents itself to prospective and current students as a Christian community of faith and learning.

\section{Therapists}

The individuals who served as co-leaders for the groups for this study were experienced in group therapy. One co-leader was a Licensed Clinical Pastoral Therapist in Tennessee, and the other co-leader was a doctoral student and primary researcher for this study. The group leaders had adequate time to become appropriately skilled in the use of the group treatment manuals. Each gained further experience with these manuals by leading a pilot study comprised of local church volunteer participants. Throughout the duration of the study the group leaders met together for a weekly 20 minute debriefing session.

\section{Treatment}

Manuals that specify the procedures for each of the nine 55-minute group sessions were developed for the treatment group (Thomas et al., 2011) and the Bible study group (Rasar, 2010). The Discovering God manual used by the treatment group is specifically geared toward God image and attachment to God in content and homework assignments. The group time also included psychoeducational components and discussion. The Spiritual Life Group manual used by the Bible study group was meant to replicate the peer led group process in which all students at the college engage as a part of their college experience called Spiritual Life Group. 
These groups focus on passages of scripture over the academic term, utilize group discussion, scripture memorization, and incorporate spiritual formation activities. The only differences in the Bible study group for this study were that it was nine weeks to match the treatment protocol and was led by two co-leaders (a licensed therapist and a doctoral student clinician).

The integrity of the treatments was evaluated through audio taped sessions and weekly debriefing sessions with the primary researcher. The primary researcher listened to the audio taped sessions each week. The sessions took place on the college campus. Adherence to the group manuals was emphasized, but the leaders had some freedom and flexibility for personal style. This flexibility did not deviate beyond the scope of the manual and the study itself.

\section{Measures}

Six measures were used in this study: the Attachment to God Inventory (Beck \& McDonald, 2004), God Image Scales (Lawrence, 1997), Spiritual Assessment Inventory (Hall \& Edwards, 2002), Brief Measure of Religious Coping Scale (Pargament et al., 1998), Theistic Spiritual Outcomes Survey (Richards et al., 2005), and Indiscriminate Proreligiousness Scale (Pargament et al.,1987). These measures were specifically selected because they assess components of the hypotheses in this study, they demonstrate acceptable psychometrics, and the combined item total enhanced the likelihood of reliable participant responses.

Attachment to God Inventory. Beck and McDonald (2004) developed a scale to operationalize the attachment to God construct. Two Attachment to God Inventory subscales are Avoidance of Intimacy and Anxiety about Abandonment. Research has demonstrated good internal consistency for both of these subscales. The Cronbach's alphas were 86 for the Avoidance of Intimacy subscale and .87 for the Anxiety about Abandonment subscale (Cooper, Bruce, Harman, \& Boccaccini, 2009). The AGI is a 28-item measure with items such as, "I worry a lot about my relationship with God" and "I am uncomfortable allowing God to control every aspect of my life." The items are rated on a 7-point Likert scale, with a response of 1 meaning disagree strongly and a 7 meaning agree strongly. Scale scores for each Avoidance of Intimacy and Anxiety about Abandonment can range from 14 to 98 .

God Image Scales. The God Image Scales (GIS; Lawrence, 1997) measure a person's God image using six subscales, including Presence (Cronbach's $\alpha=.95)$, Challenge (Cronbach's $\alpha=.81$ ), Acceptance (Cronbach's $\alpha=.83$ ), Benevolence (Cronbach's $\alpha=.84$ ), Influence (Cronbach's $\alpha=.89$ ), and Providence (Cronbach's $\alpha=89$ ). The 72-item measure includes items such as, "I can talk to God on an intimate basis," "God keeps asking me to try harder," and "God loves me regardless." Each item is rated on a 4-point Likert scale using the terms strongly agree, agree, disagree, and strongly disagree. Scale scores for each of the GIS subscales can range from 12 to 48 .

Spiritual Assessment Inventory. Hall and Edwards (2002) designed the Spiritual Assessment Inventory (SAI) to assess awareness of God and quality of relationship with God. These dimensions of the SAI include five subscales (Awareness, Realistic Acceptance, Disappointment, Grandiosity, and Instability). For the purposes of this study, the Instability (SAI-I; Cronbach's $\alpha=$.84$^{2}$ ) and Awareness (SAI-A; Cronbach's $\alpha=$ $.95)$ subscales were selected to administer to the participants. The 9-item Instability subscale and the 19-item Awareness subscale are rated on a 5-point Likert scale, with a response of 1 meaning not at all true and 5 meaning very true. Instability scale scores can range from 9 to 45. Items such as, "I am afraid that God will give up on me," and "There are times when I feel that God is punishing me," are included in the Instability subscale. Awareness scale scores can range from 19 to 95. Items such as, "God's presence feels very real to me," and "I have a sense of the direction in which God is guiding me," are included in the Awareness subscale.

Brief Measure of Religious Coping Scale. The Brief Measure of Religious Coping Scale (Brief RCOPE; Pargament et al., 1998) is a 14-item measure that assesses positive and negative patterns of religious coping methods. The positive pattern is an expression of a sense of spirituality, a secure relationship with God, the belief that there is meaning in life, and spiritual connectedness with others. The negative pattern is a less secure relationship with God, an ominous view of the world, and a religious struggle in the search for significance. In the instructions for this scale the respondent is asked to think of a recent struggle in his or her life and to identify how much the items were used in coping. Items such as, "I looked for a stronger connection with God," and "I questioned God's love for me," are rated on a 4-point Likert scale, with a response of 0 meaning not at all and 3 meaning a great deal. Validity for the scale has proved to be good, with unique variance accounted for by each subscale. The Cronbach's 
alphas were .87 and .78 for the positive pattern and negative pattern, respectively. Scores for each of these scales can range from 0 to 21 .

Theistic Spiritual Outcomes Survey. The Theistic Spiritual Outcomes Survey (TSOS; Richards et al., 2005) is a 17-item measure with items such as, "I felt God's love," "I felt forgiveness towards others," and "I loved myself," that assesses spiritual outcomes of psychotherapy from a theistic spiritual perspective. Three TSOS subscales are Love of God (Cronbach's $\alpha=.93$ ), Love of Others (Cronbach's $\alpha=.80$ ), and Love of Self (Cronbach's $\alpha=.80$ ). The individual is asked to read each item and answer how he or she felt in the past week. The items are rated on a 5-point Likert scale, with potential responses of never, rarely, sometimes, frequently, and almost always. Scores on the six-item Love of God subscale can range from 6 to 30 . Scores on the six-item Love of Others subscale can also range from 6 to 30 . Scores on the five-item Love of Self subscale can range from 5 to 25 .

Indiscriminate Proreligiousness Scale. The Indiscriminate Proreligiousness Scale (IPS; Pargament et al., 1987) was developed to measure religion expressed through personal channels (Pro-P subscale). This subscale was validated on church going students. "Indiscriminate proreligiousness is operationally defined here as a positive response to religious material regardless of its plausibility" (Pargament et al., 1987, p. 185). When this orientation is present, it tends to interfere with the measurement of religious constructs. It was used as a covariate to control for a type of social desirability in this study. The Pro-P subscale consists of 12 items (Cronbach's $\alpha=.75$ ). Items such as, "I am always inspired by the sermon topics," and "Praying always brings me inner peace," are included on the Pro-P scale. The items are rated as either true or false.

\section{Results}

The participants $(N=30)$ were randomly assigned to three groups; a treatment group $(n=11)$, a Bible study group $(n=10)$, and a wait-list control group $(n=$ 9). A data integrity check was completed for each participant, by a colleague of the primary researcher. The normality of the sample was checked via histograms, Shapiro-Wilks tests of normality, and skewness and kurtosis statistics for each group and for the sample as a whole. Even with a relatively small sample size $(N=$ $30)$, most of the dependent variables were normal $(p>$ $.05)$. Out of the 32 subscales completed by the participants, those that were not normal were within appro- priate skewness $(+/-2)$ and kurtosis $(+/-3)$ parameters. MANCOVA and ANCOVA are both robust statistics to manage these minor violations of normality (Tabachnick \& Fidell, 2006). Table 1 displays the means and standard deviations for each group for the pre-tests and post-tests for each subscale of each measure used in the study, including the Indiscriminate Proreligiousness Scale which served as the covariate.

We hypothesized that the Thomas, et al. (2011) group protocol would demonstrate improved God image and attachment to God compared to the manualized Bible study and wait-list control group. This hypothesis was not supported in its entirety. The MANCOVA results did not indicate a significant decrease in avoidant attachment to $\operatorname{God}(p=.11)$ or anxious attachment to $\operatorname{God}(p=.71)$ as measured by the AGI in the treatment group. The MANCOVA results did not indicate significantly more positive God images as measured by the combined GIS, SAI-I, and SAI-A scales in the treatment group $(p=.17)$.

Given the number of univariate ANCOVAs analyzed and the potential for false positives, $p$ was set at $\leq .01$ for significance. The results of a univariate ANCOVA indicated a trend toward more positive awareness of $\operatorname{God}(p<.05)$ as measured by the SAI-A in the treatment group compared to the wait-list control group. The results of a univariate ANCOVA also indicated a trend toward more positive God images as measured by the GIS for two of the subscales in the manualized Bible study group compared to the waitlist control group: God's presence $(p<.05)$, God's influence $(p<.05)$, and a significant increase in awareness of $\operatorname{God}(p<.01)$. Table 2 displays MANCOVA results for each hypothesis, and Table 3 displays ANCOVA results and mean group differences for each hypothesis.

We also hypothesized that both the treatment group and the Bible study would reflect improved religious coping and improved general spiritual outcomes compared to the wait-list control group. This hypothesis was partially supported. The MANCOVA results indicated a significant increase in love of God, others, and self as measured by the TSOS $(p=.05)$. Furthermore, significance was also indicated for two of the TSOS subscales and a trend towards significance in the third: Love of God $(p=.01)$, Love of Others $(p=.05)$, and Love of Self $(p=.01)$. The MANCOVA results did not indicate a significant difference in positive patterns of religious coping as measured by the Brief $\operatorname{RCOPE}(p=.74)$.

In summary, in this study there was an indication that those who participated in the treatment group and 
TABLE 1

Pre-Test and Post-Test Scores

\begin{tabular}{|c|c|c|c|}
\hline Variable & Group & $\begin{array}{l}\text { Pre-test } \\
M(S D)\end{array}$ & $\begin{array}{l}\text { Post-test } \\
M(S D)\end{array}$ \\
\hline \multirow[t]{3}{*}{ AGI_Anxiety } & Treatment & $60.20(8.7)$ & $62.58(7.9)$ \\
\hline & Bible Study & $60.20(14.1)$ & $55.44(14.7)$ \\
\hline & WLC & $59.64(11.4)$ & $60.76(15.7)$ \\
\hline \multirow[t]{3}{*}{ AGI_Avoidance } & Treatment & $43.40(13.7)$ & $47.04(12.5)$ \\
\hline & Bible Study & $46.34(14.7)$ & $38.22(11.3)$ \\
\hline & WLC & $49.14(7.1)$ & $51.24(13.5)$ \\
\hline \multirow[t]{3}{*}{ GIS_Presence } & Treatment & $27.48(4.6)$ & $25.56(4.0)$ \\
\hline & Bible Study & $23.64(6.7)$ & $20.16(5.1)$ \\
\hline & WLC & $23.64(7.0)$ & $25.32(7.1)$ \\
\hline \multirow[t]{3}{*}{ GIS_Challenge } & Treatment & $21.84(3.7)$ & $20.28(2.8)$ \\
\hline & Bible Study & $20.16(3.8)$ & $17.52(2.3)$ \\
\hline & WLC & $20.04(3.5)$ & $20.88(4.9)$ \\
\hline \multirow[t]{3}{*}{ GIS_Acceptance } & Treatment & $25.68(4.7)$ & $24.60(4.7)$ \\
\hline & Bible Study & $22.20(4.8)$ & $18.84(3.7)$ \\
\hline & WLC & $20.76(5.9)$ & $23.40(7.1)$ \\
\hline \multirow[t]{3}{*}{ GIS_Benevolence } & Treatment & $21.24(3.6)$ & $20.76(3.1)$ \\
\hline & Bible Study & $18.96(3.1)$ & $17.64(2.6)$ \\
\hline & WLC & $21.00(4.3)$ & $21.84(6.2)$ \\
\hline \multirow[t]{3}{*}{ GIS_Influence } & Treatment & $27.60(4.5)$ & $26.76(3.3)$ \\
\hline & Bible Study & $25.20(4.4)$ & $23.04(4.0)$ \\
\hline & WLC & $26.88(5.7)$ & $26.88(6.9)$ \\
\hline \multirow[t]{3}{*}{ GIS_Providence } & Treatment & $29.88(3.0)$ & $28.56(3.5)$ \\
\hline & Bible Study & $27.24(5.3)$ & $24.96(2.9)$ \\
\hline & WLC & $29.04(4.2)$ & $27.84(5.6)$ \\
\hline \multirow[t]{3}{*}{ SAI_Instability } & Treatment & $26.91(6.0)$ & $26.82(6.0)$ \\
\hline & Bible Study & $25.20(5.9)$ & $25.38(6.6)$ \\
\hline & WLC & $25.92(6.0)$ & $25.56(7.6)$ \\
\hline \multirow[t]{3}{*}{ SAI_Awareness } & Treatment & $54.53(15.0)$ & $61.75(13.0)$ \\
\hline & Bible Study & $63.65(14.6)$ & $76.00(14.2)$ \\
\hline & WLC & $63.27(14.4)$ & $60.80(18.9)$ \\
\hline \multirow[t]{3}{*}{ RCOPE_Positive } & Treatment & $13.02(3.6)$ & $15.19(2.3)$ \\
\hline & Bible Study & $12.39(2.5)$ & $16.17(2.9)$ \\
\hline & WLC & $15.54(4.3)$ & $15.68(1.5)$ \\
\hline \multirow[t]{3}{*}{ RCOPE_Negative } & Treatment & $6.30(4.4)$ & $6.09(5.0)$ \\
\hline & Bible Study & $5.88(4.3)$ & $6.23(3.7)$ \\
\hline & WLC & $5.11(6.0)$ & $6.65(4.9)$ \\
\hline \multirow[t]{3}{*}{ TSOS_Love of God } & Treatment & $17.70(3.1)$ & $21.00(2.6)$ \\
\hline & Bible Study & $20.82(6.0)$ & $25.50(4.3)$ \\
\hline & WLC & $21.00(2.8)$ & $20.64(4.5)$ \\
\hline \multirow[t]{3}{*}{ TSOS_Love of Others } & Treatment & $22.56(2.1)$ & $24.00(3.8)$ \\
\hline & Bible Study & $22.62(3.2)$ & $27.12(2.8)$ \\
\hline & WLC & $22.02(3.4)$ & $23.22(3.4)$ \\
\hline
\end{tabular}


TABLE 1

Continued

\begin{tabular}{llcc}
\hline Variable & Group & $\begin{array}{c}\text { Pre-test } \\
M(S D)\end{array}$ & $\begin{array}{c}\text { Post-test } \\
M(S D)\end{array}$ \\
\hline TSOS_Love of Self & Treatment & $14.45(2.6)$ & $15.10(2.7)$ \\
& Bible Study & $15.00(3.4)$ & $18.00(4.3)$ \\
WPS_Pro-P & WLC & $18.55(2.1)$ & $14.90(3.8)$ \\
\hline
\end{tabular}

Note. Treatment Group, $n=11$; Comparable Group $n=10$; Wait List Control (WLC) Group, $n=9 ; A G I$

= Attachment to God Inventory; GIS = God Image Scales; SAI = Spiritual Assessment Inventory; RCOPE

$=$ Brief Measure of Religious Coping Scales; TSOS = Theistic Spiritual Outcome Survey. The score range for cach 14 item AGI subscalc was 14 to 98. The scorc range for cach 12 item GIS subscalc was 12 to 48 . The

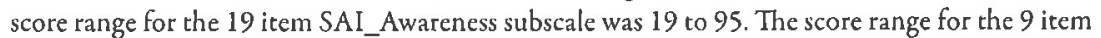

SAI_Instability subscale was 9 to 45 . The score range for each $7 \mathrm{item}$ RCOPE subscale was zero to 21 . The score range for the six item TSOS_Love of God and the six item TSOS_Love of Others subscales was 6 to 30. The score range for the five item TSOS_Love of Self subscale was 5 to 25. The score range for the 12 item IPS_Pro P Subscalc was 12 to 24. The IPS-Pro P was used as a covariatc.

Bible study group experienced an overall significant increase in love of God, others, and self compared to the wait list control group. Also, the mean group differences indicated a significant increase in three God images; God's presence, God's influence, and awareness of God by the participants of the manualized Bible study group, and an increase in awareness of God by the treatment group. Overall, the Bible study group showed more change than the treatment group.

\section{Discussion}

This study randomized participants into a God image treatment protocol, manualized Bible study, and a wait-list control group to compare their efficacy in regards to changing God image, God attachment, religious coping, and general spiritual outcomes such as increasing one's love of God, others, and self. No significant changes in God attachment (measured by AGI), God image (measured by GIS and SAI), or religious coping (measured by Brief RCOPE) were noted in the treatment protocol compared to the Bible study. An increase in general spiritual outcomes (love of God, others, and self as measured by the TSOS) was observed in both the treatment protocol and the manualized Bible study compared to the wait-list control group. Review of the pre-test and post-test means suggest that changes were likely greater in the Bible study group compared to the treatment group.

Essentially, this study suggests common core elements in spiritually-focused groups may produce positive spiritual outcomes but the question of how to produce positive God attachment change remains unanswered. Moreover, the value of small group spiritual formation-focused Bible studies in general in the Christian college and university environments is supported since both groups exhibited significant changes compared to the wait-list control group that did not improve on any of this study's measures.

The results are not congruent with the Thomas et al. (2011) study. Although both studies incorporated the same treatment manual, this study had several methodological improvements. The current study was randomized, included a manualized Bible study comparison group, and had a wait-list control group. The Thomas et al. study included some participants that were simultaneously engaged in individual therapy and the group treatment, while this study excluded potential participants that were currently in individual therapy. Furthermore, this study utilized multiple quantitative measures, as opposed to 'Thomas' study, which utilized only the Attachment to God Inventory. Since the results of this study contradict the Thomas et al. (2011) study, perhaps God attachment change may be harder to realize than anticipated.

This study's design improvements strengthen the interpretability of its results compared to the Thomas et al. study; however, other factors may also contribute to the differences in results. Specifically, the treatment protocol used may need to be revised based on age cohort and developmental differences in the samples studied. For example, the mean age in the Thomas study was 30 and the mean age in this study was 20 . 
TABLE 2

MANCOVA Post Results

\begin{tabular}{|c|c|c|c|c|c|}
\hline Variable & Group & $M$ & $F$ & $p$ & Partial $\eta^{2}$ \\
\hline \multirow[t]{4}{*}{ AGI_Anxiety } & Total Sample & & .34 & .71 & .03 \\
\hline & Treatment & 4.23 & & & \\
\hline & Bible Study & 4.14 & & & \\
\hline & WLC & 4.43 & & & \\
\hline \multirow[t]{4}{*}{ AGI_Avoidance } & Total Sample & & 2.43 & .11 & .17 \\
\hline & Treatment & 3.36 & & & \\
\hline & Bible Study & 2.83 & & & \\
\hline & WLC & 3.54 & & & \\
\hline \multirow[t]{4}{*}{ GIS_Presence } & Total Sample & & 4.84 & .02 & .35 \\
\hline & Treatment & 1.93 & & & \\
\hline & Bible Study & 1.76 & & & \\
\hline & WLC & 2.26 & & & \\
\hline \multirow[t]{4}{*}{ GIS_Challenge } & Total Sample & & 2.60 & .10 & .22 \\
\hline & Treatment & 1.60 & & & \\
\hline & Bible Study & 1.48 & & & \\
\hline & WLC & 1.83 & & & \\
\hline \multirow[t]{4}{*}{ GIS_Acceptance } & Total Sample & & 3.26 & .06 & .27 \\
\hline & Treatment & 1.90 & & & \\
\hline & Bible Study & 1.61 & & & \\
\hline & WLC & 2.09 & & & \\
\hline \multirow[t]{4}{*}{ GIS_Benevolence } & Total Sample & & 2.2 & .13 & .20 \\
\hline & Treatment & 1.62 & & & \\
\hline & Bible Study & 1.53 & & & \\
\hline & WLC & 1.89 & & & \\
\hline \multirow[t]{4}{*}{ GIS_Influence } & Total Sample & & 3.79 & .04 & .30 \\
\hline & Treatment & 2.08 & & & \\
\hline & Bible Study & 1.95 & & & \\
\hline & WLC & 2.40 & & & \\
\hline \multirow[t]{4}{*}{ GIS_Providence } & Total Sample & & 1.48 & .26 & .14 \\
\hline & Treatment & 2.25 & & & \\
\hline & Bible Study & 2.16 & & & \\
\hline & WLC & 2.39 & & & \\
\hline \multirow[t]{4}{*}{ SAI_Instability } & Total Sample & & .11 & .89 & .01 \\
\hline & Treatment & 2.91 & & & \\
\hline & Bible Study & 2.80 & & & \\
\hline & WLC & 2.96 & & & \\
\hline \multirow[t]{4}{*}{ SAI_Awareness } & Total Sample & & 8.23 & .00 & .48 \\
\hline & Treatment & 3.64 & & & \\
\hline & Bible Study & 3.88 & & & \\
\hline & WLC & 2.86 & & & \\
\hline \multirow[t]{4}{*}{ RCOPE_Positive } & Total Sample & & .88 & .43 & .07 \\
\hline & Treatment & 2.19 & & & \\
\hline & Bible Study & 2.36 & & & \\
\hline & WLC & 2.16 & & & \\
\hline \multirow[t]{4}{*}{ RCOPE_Negative } & Total Sample & & .15 & .87 & .01 \\
\hline & Treatment & .82 & & & \\
\hline & Bible Study & .93 & & & \\
\hline & WLC & .97 & & & \\
\hline
\end{tabular}


TABLE 2

Continued

\begin{tabular}{|c|c|c|c|c|c|}
\hline Variable & Group & $M$ & $F$ & $p$ & Partial $\eta^{2}$ \\
\hline \multirow[t]{4}{*}{ TSOS_Love of God } & Total Sample & & 5.74 & .01 & .33 \\
\hline & Treatment & 3.75 & & & \\
\hline & Bible Study & 4.24 & & & \\
\hline & WLC & 3.15 & & & \\
\hline \multirow[t]{4}{*}{ TSOS_Love of Others } & Total Sample & & 4.04 & .03 & .26 \\
\hline & Treatment & 3.96 & & & \\
\hline & Bible Study & 4.56 & & & \\
\hline & WLC & 3.87 & & & \\
\hline \multirow[t]{4}{*}{ TSOS_Love of Self } & Total Sample & & 6.70 & .01 & .37 \\
\hline & Treatment & 3.13 & & & \\
\hline & Bible Study & 3.84 & & & \\
\hline & WLC & 2.57 & & & \\
\hline
\end{tabular}

Note. AGI = Attachment to God Inventory; GIS = God Image Scales; SAI = Spiritual Assessment Inventory; RCOPE = Brief Measure of Religious Coping Scale; TSOS = Theistic Spiritual Outcome Survey. Total Samplc, $N=30$; Treatment Group, $n=11$; Comparable Group $n=10$; Wait List Control (WLC) Group, $n=9 ; d f=2$. Covariate appears in the model.

TABLE 3

ANCOVA Results of Post Mean Group Differences

\begin{tabular}{|c|c|c|c|c|}
\hline Variable & Group (I) & Group $(J)$ & Mean Difference (I-J) & $p$ \\
\hline \multirow[t]{6}{*}{ AGI_Anxiety } & \multirow[t]{2}{*}{ Treatment } & Bible Study & .09 & .99 \\
\hline & & Wait List & -.20 & .93 \\
\hline & \multirow{2}{*}{ Bible Study } & Treatment & -.09 & .99 \\
\hline & & Wait List & -.29 & .81 \\
\hline & \multirow[t]{2}{*}{ WLC } & Treatment & .20 & .93 \\
\hline & & Bible Study & .29 & .81 \\
\hline \multirow[t]{6}{*}{ AGI_Avoidance } & \multirow[t]{2}{*}{ Treatment } & Bible Study & .54 & .35 \\
\hline & & Wait List & -.18 & .94 \\
\hline & \multirow[t]{2}{*}{ Bible Study } & Treatment & -.54 & .35 \\
\hline & & Wait List & -.72 & .12 \\
\hline & \multirow[t]{2}{*}{ WLC } & Treatment & .18 & .94 \\
\hline & & Bible Study & .72 & .12 \\
\hline \multirow[t]{6}{*}{ GIS_Presence } & \multirow[t]{2}{*}{ Treatment } & Bible Study & .17 & .57 \\
\hline & & Wait List & -.33 & .20 \\
\hline & \multirow[t]{2}{*}{ Bible Study } & Treatment & -.17 & .57 \\
\hline & & Wait List & $-.51^{*}$ & .02 \\
\hline & \multirow[t]{2}{*}{ Wait List } & Treatment & .33 & .20 \\
\hline & & Bible Study & $.51^{*}$ & .02 \\
\hline \multirow[t]{7}{*}{ GIS_Challenge } & \multirow[t]{2}{*}{ Treatment } & Bible Study & .11 & .79 \\
\hline & & Wait List & -.22 & .43 \\
\hline & \multirow[t]{2}{*}{ Bible Study } & Treatment & -.12 & .79 \\
\hline & & Wait List & -.34 & .10 \\
\hline & \multirow[t]{3}{*}{ Wait List } & Treatment & .23 & .43 \\
\hline & & Bible Study & .34 & .10 \\
\hline & & & (Table contin & tpage) \\
\hline
\end{tabular}


TABLE 3

Continued

\begin{tabular}{|c|c|c|c|c|}
\hline Variable & Group (I) & Group $(J)$ & Mean Difference (I-J) & $p$ \\
\hline \multirow[t]{6}{*}{ GIS_Acceptance } & \multirow[t]{2}{*}{ Treatment } & Bible Study & .29 & .31 \\
\hline & & Wait List & -.18 & .77 \\
\hline & \multirow[t]{2}{*}{ Bible Study } & Treatment & -.29 & .31 \\
\hline & & Wait List & -.47 & .08 \\
\hline & \multirow[t]{2}{*}{ Wait List } & Treatment & .18 & .77 \\
\hline & & Bible Study & .47 & .08 \\
\hline \multirow[t]{6}{*}{ GIS_Benevolence } & \multirow[t]{2}{*}{ Treatment } & Bible Study & .09 & .92 \\
\hline & & Wait List & -.27 & .39 \\
\hline & \multirow[t]{2}{*}{ Bible Study } & Treatment & -.09 & .92 \\
\hline & & Wait List & -.36 & .14 \\
\hline & \multirow[t]{2}{*}{ Wait List } & Treatment & .27 & .39 \\
\hline & & Bible Study & .36 & .14 \\
\hline \multirow[t]{6}{*}{ GIS_Influence } & \multirow[t]{2}{*}{ Treatment } & Bible Study & .13 & .77 \\
\hline & & Wait List & -.32 & .23 \\
\hline & \multirow[t]{2}{*}{ Bible Study } & Treatment & -.13 & .77 \\
\hline & & Wait List & $-.46^{*}$ & .04 \\
\hline & \multirow[t]{2}{*}{ Wait List } & Treatment & .32 & .23 \\
\hline & & Bible Study & $.46^{*}$ & .04 \\
\hline \multirow[t]{6}{*}{ GIS_Providence } & \multirow[t]{2}{*}{ Treatment } & Bible Study & .08 & .87 \\
\hline & & Wait List & -.14 & .68 \\
\hline & \multirow[t]{2}{*}{ Bible Study } & Treatment & -.08 & .87 \\
\hline & & Wait List & -.22 & .28 \\
\hline & \multirow[t]{2}{*}{ Wait List } & Treatment & .14 & .68 \\
\hline & & Bible Study & .22 & .28 \\
\hline \multirow[t]{6}{*}{ SAI_Instability } & \multirow[t]{2}{*}{ Treatment } & Bible Study & .11 & .98 \\
\hline & & Wait List & -.05 & .99 \\
\hline & \multirow[t]{2}{*}{ Bible Study } & Treatment & -.11 & .98 \\
\hline & & Wait List & -.16 & .96 \\
\hline & \multirow[t]{2}{*}{ Wait List } & Treatment & .05 & .99 \\
\hline & & Bible Study & .16 & .96 \\
\hline \multirow[t]{6}{*}{ SAI_Awareness } & \multirow[t]{2}{*}{ Treatment } & Bible Study & -.25 & .65 \\
\hline & & Wait List & $.78^{*}$ & .03 \\
\hline & Bible Study & Treatment & .25 & .65 \\
\hline & & Wait List & $1.03^{* *}$ & .00 \\
\hline & Wait List & Treatment & $-.78^{*}$ & .03 \\
\hline & & Bible Study & $-1.03^{* *}$ & .00 \\
\hline RCOPE_Positive & Treatment & Bible Study & -.16 & .65 \\
\hline & & Wait List & .04 & .99 \\
\hline & Bible Study & Treatment & .16 & .65 \\
\hline & & Wait List & .20 & .55 \\
\hline & WLC & Treatment & -.04 & .99 \\
\hline & & Bible Study & -.20 & .55 \\
\hline RCOPE_Negative & Treatment & Bible Study & -.11 & .97 \\
\hline & & Wait List & -.15 & .94 \\
\hline & Bible Study & Treatment & .11 & .97 \\
\hline & & Wait List & -.04 & .99 \\
\hline & WLC & Treatment & .15 & .94 \\
\hline & & Bible Study & .04 & .99 \\
\hline & & & (Table contin & tpage) \\
\hline
\end{tabular}


TABLE 3

Continued

\begin{tabular}{lllcl}
\hline Variable & Group (I) & Group $(\mathrm{J})$ & Mean Difference $(\mathrm{I}-\mathrm{J})$ & $p$ \\
\hline TSOS_God & Treatment & Bible Study & -.49 & .25 \\
& & Wait List & .60 & .23 \\
& Bible Study & Treatment & .49 & .25 \\
& & Wait List & $1.08^{* *}$ & .01 \\
& Wait List & Treatment & -.60 & .23 \\
& & Bible Study & $-1.08^{* *}$ & .01 \\
TSOS_Others & Treatment & Bible Study & -.59 & .07 \\
& & Wair List & .09 & .99 \\
& Bible Study & Treatment & .59 & .07 \\
& & Wait List & .68 & .08 \\
& Wait List & Treatment & -.09 & .99 \\
& & Bible Study & -.68 & .08 \\
TSOS_Self & Treatment & Bible Study & -.71 & .09 \\
& & Wait List & .55 & .38 \\
& Bible Study & Treatment & .71 & .09 \\
& Wait List & $1.27^{* *}$ & .01 \\
& Wait List & Treatment & -.55 & .38 \\
& & Bible Study & $-.12^{* *}$ & .01 \\
\hline
\end{tabular}

Note. AGI = Attachment to God Inventory; GIS = God Image Scales; SAI = Spiritual Assessment Inventory; RCOPE = Brief Measure of Religious Coping Scale; TSOS = Theistic Spiritual Outcome Survey. Based on estimated marginal means. $d f=2$.

a. Adjustment for multiple comparisons: Sidak.

* The mean difference suggests a trend at the .05 level.

*"The mean differcluce is significant at the .01 level.

Perhaps the treatment group manual is better suited for an adult population that is not in an undergraduate college setting.

Observations of the group counselors seem to support the role of cohort differences compared to the Thomas et al. (2011) study. The age difference (mean of 20 in this study and 30 in the Thomas et al. study), developmental differences, educational level, spiritual maturity, and peer-led spiritual life group context compared to the clinical context of the Thomas et al. (2011) study may have all contributed to the different findings.

Two different treatment protocol responses compared to the Thomas et al. (2011) study will be noted. First, the initial four treatment protocol sessions were primarily experiential and the last four utilized more rational emotive interventions. Group member engagement appeared to decrease when the treatment group manual shifted away from the experiential components. In the second example, the reading of C.S. Lewis' book, The Horse and His Boy, was noted by Thomas et al. as having meaningful impact on their participants. It did not seem to have the same positive impact on the participants in this study. We surmise that assigned bibliotherapy with young college age students may not be as effective as it is with other populations due to the number of books they are already reading in their academic endeavors.

Additional treatment protocol enhancements may likewise benefit future studies. More emphasis on comparing and contrasting the group members' families of origin and their experiences with their parents may profit participants. While the treatment protocol used in this study included a family of origin component, time was limited for detailed group discussion on this topic. In another example, one session included an exercise in which the participants were asked to visualize a time in their lives that involved regret, with a homework exercise asking participants to write a letter to themselves "from God." Time was limited for much group discussion on this activity, but group members indicated they would have liked this part of the group process to fill an entire session. Finally, the treatment protocol may have benefited from the incorporation of 
contemplative prayer, spiritual formation exercises, inner healing prayer, and perhaps longer time length to permit better processing of new information.

The nature of the Bible study group also may have had an impact on the results. The entire Bible study group protocol emphasized just one passage of scripture (Psalm 8), included ample time for group discussion, and incorporated homework assignments that were primarily spiritual formation exercises. The interpersonal and experiential aspects of this type of Bible study may have contributed to the intriguing positive spiritual outcomes on the TSOS. To our knowledge, this is the first preliminary empirical support for the efficacy of small group, spiritual formation-focused Bible studies.

Future research using a revised treatment group manual and replicating the randomization and Bible study group design is recommended to strengthen the understanding of the impact of group treatment on God image and God attachment change. Also, future studies might consider the efficacy of short-term groups compared to long-term groups or individual therapy in regards to God image and God attachment change.

\section{Limitations}

There were several limitations in this study that should be considered in interpreting its results. The scope of this study was intentionally limited to the Bible college context and non-clinical population. Peer prayer groups were a common element of the community from which participants were drawn, so the motivation of participants could have varied. While motivation appeared good to the researchers, this context could contribute to the limited results for the treatment group. The sample size was quite small $(N=30)$ and included only college students attending a Christian university. Future research with larger samples, greater ethnicity and age diversity, and beyond the context of a Christian college would amplify the knowledge base on God image and attachment to God treatment and change. Finally, a longitudinal outcomes component would provide further insight into the maintenance of any God image, God attachment, and religious coping change.

\section{References}

Ainsworth, M. D. S. (1985). Attachment across the lifespan. Bulletin of the New York Academy of Medicine, 61, 792-812.

Barlow, S. H., Burlingame, G. M., \& Fuhriman, A. (2000). Therapcutic application of groups: From Pratt's "thought control classes" to modern group psychotherapy. Group Dynamics, Theory, Research, and Practice, 4, 115-134.
Beck, R. (2006). God as a secure base: Attachment to God and theological exploration. Journal of Psychology and Theology, 34, 125-132.

Beck, R., \& McDonald, A. (2004). Attachment to God: The attachment to God inventory, tests of working model correspondence, and an exploration of faith group differences. Journal of Psychology and Theology, 32, 92-103.

Birky, I. T., \& Ball, S. (1988). Parental trait influence on God as an object representation. Journal of Psychology, 122, 133-137.

Bowlby, J. (1969, 1982). Attachment and loss: Attachment (Vol. 1, $2^{\text {nd }}$ ed.). New York: Basic Books.

Cheston, S. E., Piedmont, R. L., Eanes, B,, \& Lavin, L. P. (2003). Changes in clients' images of God over the course of outpatient therapy. Counseling and Values, 47, 96-108.

Cooper, L. B., Bruce, A. J., Harman, M. J., \& Boccaccini, M. T. (2009). Differentiated styles of attachment to God and varying religious coping cfforts. Journal of Psychology of Theology, 37, 134-141.

Davis, E. B. (2010). Authenticity, inauthenticity, attacbment, and God-image tendencies among adult evangelical Protestant Christians (Doctoral disscitation). Retricved from Pro Quest Disscrtations \& Theses. (AAT 3400639).

Fosshage, J. L. (2003). Fundamental pathways to change: Illuminating old and creating new relational experience. International Forum of Psychoanalysis, 12, 244-251.

Garzon, F. L. (2007). Neuroscientific contributions to God image therapy and theory. In G. Moriarty \& L. Hoffman (Ed.), The God image bandbook for spiritual counseling and psychotherapy (pp. 139155). Binghampton, NY: Haworth Press.

Gorey, K. M., Richter, N. L., \& Snider, E. (2001). Guilt, isolation and hopelessless among female survivors of childhood sexual abuse: Effectiveness of group work intervention. Child Abuse \& Neglect, 25, 347-355.

Granqvist, P., \& Hagekull, B. (1999). Religiousness and perceived childhood attachment: Profiling socialized correspondence and emotional compensation. Journal for the Scientific Siudy of Religion, $38,254-273$.

Grimes, C. (2007). God image research: A literature review. In G. Moriarty \& L. Hoffman (Ed.), The God image bandbook for spiritual counseling and psychotherapy (pp. 139-155), Binghampton, NY: Haworth Press.

Hall, T. W. (2004). Christian spirituality and mental health: A relational spirituality paradigm for empirical research. Journal of Psychology and Cbristianity, 23, 66-81.

Hall, T. W. (2007). Psychoanalysis, attachment, and spirituality Part I: The cmergence of two relational traditions. Journal of Psychology and Theology, 35, 14-28.

Hall, T. W., \& E.dwards, K. J. (2002). The spiritual assessment inventory: A theistic model and measure for assessing spiritual development. Journal for she Scientific Study of Religion, 41, 341-357.

Hall, T.W., Halcrow, S., Hill, P.C., \& Delaney, H. (August, 2005). Internal working model correspondence in implicit spiritual experiences. Paper presented at the $113^{\text {th }}$ Annual Convention of the American Psychological Association, Washington, DC.

Hall, T. W., Fujikawa, A., Halcrow, S. R., Hill, P. C., \& Delaney, H. (2009). Attachment to God and implicit spirituality: Clarifying 
correspondence and compensation models. Journal of Psychology and Theology, 37, 227-244.

Hoffman, L. (2005). A developmental perspective on the God image. In R. H. Cox, B. Ervin-Cox, \& L. Hoffman (Eds.), Spirituality and psychological health (pp. 129-147). Colorado Springs, CO: Colorado School of Professional Psychology Press.

Jacques, J. R. (1998). Working with spiritual and religious themes in group thcrapy. The International Journal of Group Psychotherapy, 48, 69-83.

Key, T. L. (1995). Impact of inpatient psychiatric treatment on object relations maturity, self-esteem and God image. (Doctoral Dissertation, Rosemead School of Psychology, Biola University, 1995). Dissertation Abstracts International, 55(12-B), 5568.

Kirkpatrick, L. A. (1992). An atcachment-theory approach to the psychology of religion. International Journal for the Psychology of Religion, 4, 3-28.

Kirkpatrick, L. A. (1999). Artachment and religious representations and behavior. In J. Cassidy \& P. R. Shaver (Ed.), Handbook of attachment: Theory, research, and clinical applications (pp. 803-822). New York: Guilford Press.

Kirkpatrick, L. A., \& Shaver, P. R. (1990). Attachment theory and religion: Childhood attachments, religious beliefs, and conversion. Journal for the Scientific Study of Religion, 29, 315-334.

Kirkpatrick, L. A., \& Shaver, P. R. (1992). An attachment-theoretical approach to romantic love and religious belief. Personality and Social Psychology Bulletin, 18, 266-275.

Klein, M. (1930/1964). The importance of symbol formation in the development of the ego. In M. Klein, Contributions to psychoanalysis, 1921-1945 (pp. 236-250). New York: McGraw-Hill.

Lawrence, R. T. (1997). Measuring the image of God: The God image inventory and the God image scales. Journal of Psychology and Theology, 25, 214-226.

McDargh, J. (1986). God, mother and me: An object relational perspective on religious material. Pastoral Psychology, 34, 251-263.

McDermut, W., Miller, I. W., \& Brown, R. A. (2001). The efficacy of group psychotherapy for depression: A meta-analysis and review of the empirical research. Clinical Psychology: Science and Practice, 8, 98-116.

McDonald, A., Beck, R. A., Allison, S., \& Norsworthy, L. (2005). Attachment to God and parents: Testing correspondence vs. compensation hypotheses. Journal of Psychology and Christianity, 24, 21-28.

Moriarty, G. L., \& Davis, E. B. (in press). Client God images: Theory, research, and clinical practice. In K. O'Grady, E. Worthington, Jr., \& J. Aten (Eds.), The psychology of religion and spirituality for clinicians: Using research in your practice. New York, NY: Routledge.

O'Hare, C. A. (2003). Challenging God images: Implementing a Christian component with a standard group therapy intervention. Dissertation Abstracts International, 63(8-B), 3932.

Peloso, J. M. (2008). Adult images of God: Implications for pastoral counseling. Journal of Pastoral Counseling, 43, 15-31.

Pargament, K. I., Brannick, M. T., Adamakos, H., Ensing, D. S., Kelemen, M. L., Warren, R. K., Falgout, K., Cook, P., \& Myers, J.
(1987). Indiscriminant proreligiousness: Conceptualization and measurement. Journal for the Scientific Study of Religion, 26, 182200.

Pargament, K. I., Smith, B. W., Koenig, H. G., \& Perez, L. (1998). Patterns of positive and negative coping with major life stressors. Journal for the Scientific Study of Religion, 37, 710-724.

Rasar, J. D. (2010). Spiritual life group. Unpublished manuscript, Center for Counseling and Family Studies, Liberty University, Lynchburg, Virginia.

Richards, P. S., Smith, T. B., Schowalter, M., Richard, M., Berrett, M. E., \& Hardman, R. K. (2005). Development and validation of the theistic spiritual outcome survey. Psychotherapy Research, 15, 457-469.

Rizzuto, A. (1974). Object relations and the formation of the image of God. British Journal of Medical Psychology, 47, 83-99.

Rizzuto, A. (1979). The birth of the living God. Chicago: University of Chicago Press.

Schore, A. (2002). Advances in neuropsychoanalysis, attachment theory, and trauma research: Implications for self-psychology. $P_{s y-}$ choanalytic Inquiry, 22, 433-484.

Sperry, L. (2005). Integrative spiritually oriented psychotherapy. In L. Sperry \& E. Shafranske (Ed.), Spiritually oriented psychotherapy (pp. 31-50). Washington, DC: American Psychological Association.

Tabachnick, B. D., \& Fidell, L. S. (2006). Using multivariate statistics (5 $5^{\text {th }}$ Edition). Boston: Allyn \& Bacon.

Thomas, M. J., Moriarty, G. L., Davis, E. B., \& Anderson, E. L. (2011). The effects of a manualized group-psychotherapy intervention on client God images and attachment to God: A pilot study. Journal of Psychology and Theology, 39, 44-58.

Tisdale, T. C., Key, T. L., Kemperman, S. R., Cloud, H., Townsend, J., \& Okamoto, T. (1997). Impact of treatment on God image and personal adjustment, and correlations of God image to personal adjustment and object relations development. Journal of Psychology and Theology, 25, 227-239.

\section{Author Information}

RASAR, JACQUELINE D. Ph.D. Address: 114 Tamarisk St., Redlands, CA 92373. Email: jdrasar@liberty.edu. Title: Adjunct Instructor, Liberty University, Lynchburg, VA. Degree: PhD (Professional Counseling)

GARZON, FERNANDO L. Psy.D. Address: Center for Counseling and Family Studies, 1971 University Blvd., Liberty University, Lynchburg, Virginia 24515.

MORIARTY, GLENDON L. Psy.D. Address: School of Psychology and Counseling, Doctoral Program in Clinical Psychology, Regent University, Virginia Beach, Virginia 23464;

VOLK, FREDERICK. Address: Center for Counseling and Family Studies, Liberty University, 1971 University Blyd, Lynchburg, Virginia 24515;

O'HARE, CARMElla A. Address: Center for Counseling and Family Studies, Liberty University, 1971 University Blvd, Lynchburg, Virginia 24515. 